\title{
PENGUJIAN KANDUNGAN INFORMASI ARUS KAS DAN LABA AKUNTANSI TERHADAP RETURN SAHAM: STUDI PADAPERUSAHAAN LQ45
}

\author{
Samsul Hadi \\ Magister Akuntansi, Universitas Pancasila \\ samsul28754@yahoo.co.id \\ Syahril Djaddang \\ Magister Akuntansi, Universitas Pancasila \\ Suyanto \\ STIE IPWI \\ Diterima 31 Juli 2017, Disetujui 8 Agustus 2017
}

\begin{abstract}
Abstrak
Tujuan penelitian ini untuk menganalisis pengaruh perubahan arus kas operasi, arus kas investasi, arus kas pendanaan, dan laba akuntansi terhadap return saham di pasar modal Indonesia. Penelitian dilakukan terhadap 15 perusahaan yang terdaftar dalam Indeks LQ45 di Bursa Efek Indonesia (BEI). Pengamatan dilakukan selama 4 tahun mulai tahun 2011 sampai dengan tahun 2014. Analisis data menggunakan analisis data panel. Hasil penelitian menunjukkan bahwa arus kas operasi dan arus kas pendanaan berpengaruh signifikan terhadap return saham. Hal ini berarti setiap peningkatan dalam arus kas operasi dan pengeluaran untuk aktivitas pendanaan diikuti dengan peningkatan return saham. Laba akuntansi dan arus kas investasi tidak berpengaruh secara signifikan terhadap return saham, karena kandungan informasi akuntansi dan arus kas investasi pada perusahaan sampel tidak mengandung informasi yang relevan dan masih terjadi anomali pasar di akibatkan kegagalan investor memahami informasi akrual, arus kas, risiko pasar dan konservatisma.
\end{abstract}

Kata kunci: arus kas operasi, arus kas investasi, arus kas pendanaan, laba akuntansi, return saham.

\section{Abstract}

This study aimed to analyze the effect of changes in cash flow from operating activities, cash flows from investing avtivities, cash flow from financing activities and accounting earnings on stock returns in the Indonesian capital market. Research conducted on 15 companies listed in the LQ45 index in the Indonesia Stock Exchange (BEI). Observations were made for 4 years from 2011 to 2014. Data were analyzed using data panel analysis. The results show that operating cash flow and financing cash flow significantly influence stock returns. This means any increase in operating cash flow and in expenditures for financing activities followed by an increase in stock returns. Accounting earnings and cash flows have no significant effect on stock returns, since the accounting information and investment cash flows of the sample companies do not contain relevant information and market anomalies occur due to investor failure to understand accrual information, cash flow, market risk and conservatism.

Keywords: operating cash flow, investing cash flow, financing cash flow, earnings, stock returns 


\section{PENDAHULUAN}

Pasar modal merupakan sarana yang digunakan untuk menyalurkan dana yang bersumber dari masyarakat ke berbagai sektor untuk melaksanakan aktivitas investasinya dalam bentuk surat-surat berharga. Salah satu jenis investasi surat berharga adalah saham. Tujuan investor berinvestasi di pasar modal adalah untuk mendapatkan return. Return saham merupakan tingkat pendapatan yang diperoleh dengan mengurangkan harga penutupan saham saat ini dengan harga penutupan saham sebelumnya kemudian dibagi dengan harga penutupan tahun sebelumnya. Agar investor merasa aman untuk berinvestasi, investor harus bisa mengukur risiko serta memperkirakan pendapatan yang akan diperolehnya (Putriani dan Sukartha, 2014). Untuk itu investor perlu memperhatikan kenaikan dan penurunan harga saham. Indeks harga saham perusahaan yang termasuk dalam daftar indeks LQ45 untuk periode 2011 sampai dengan 2014 mengalami fluktuasi. Fenomena gap terlihat bahwa pada tahun 2012 return saham mengalami kenaikan 398\%, pada tahun 2013 mengalami penurunan sebesar $136 \%$, dan kemudian pada tahun 2014 mengalami kenaikan yang sangat signifikan sebesar $910 \%$. Besarnya return saham tertinggi terjadi pada tahun 2014 sebesar $26,36 \%$, dan return saham terendah terjadi pada tahun 2013 sebesar $-3,25 \%$, dapat digambarkan pada tabel 1 berikut ini:

Tabel 1. Indeks Harga Saham LQ45 Periode 2011-2014

\begin{tabular}{ccccc}
\hline $\begin{array}{c}\text { Periode } \\
\text { Tahun }\end{array}$ & Awal & Akhir & Perubahan & Persentase \\
\hline 2014 & 711.135 & 898.581 & 187.446 & $26.36 \%$ \\
2013 & 735.042 & 711.135 & -23.907 & $-3.25 \%$ \\
2012 & 673.506 & 735.042 & 61.536 & $9.14 \%$ \\
2011 & 661.378 & 673.506 & 12.128 & $1.83 \%$ \\
\hline
\end{tabular}

Beberapa penelitian di luar negeri telah dilakukan baik di bidang akuntansi maupun keuangan untuk mengetahui keterkaitan antara informasi yang terdapat dalam laporan arus kas dengan perubahan harga atau return saham. Seperti yang dikutip oleh Triyono dan Jogiyanto (2000) adalah sebagai berikut: Wilson (1986,1987), Rayburn (1986), dan Bowen $(1986,1987)$ menguji kandungan-kandungan informasi arus kas dan laba dengan return saham. Dari hasil penelitiannya mereka menemukan adanya kandungan informasi pada data arus kas. Sedangkan peneliti lain seperti, Board dan Day (1989), yang menguji apakah data arus kas mempunyai kandungan informasi dalam hubungannya dengan harga saham. Hasil penelitian mereka menunjukkan bahwa data arus kas tidak mempunyai kandungan informasi dalam hubungannya dengan saham. Livnat dan Zarowin (1990) menguji komponen arus kas seperti yang direkomendasikan oleh SFAS No. 95. Hasil penelitiannya menemukan bahwa komponen arus kas mempunyai hubungan yang lebih kuat dengan abnormal return saham dibandingkan dengan hubungan total arus kas dengan abnormal return saham.

Sedangkan di Indonesia, penelitian mengenai arus kas juga telah dilakukan oleh beberapa peneliti. Hastuti (1997), dalam penelitiannya menyimpulkan bahwa laporan arus kas mempunyai kandungan informasi, yang terbukti dari adanya peningkatan volume perdagangan saham 3 hari di seputar tanggal publikasi laporan keuangan. Triyono dan Jogiyanto (2000), menyimpulkan bahwa dengan model levels menunjukkan bahwa total arus kas tidak mempunyai hubungan yang signifikan dengan harga saham, tetapi pemisahan total arus kas ke dalam 3 komponen arus kas mempunyai hubungan signifikan dengan harga saham. Rohman (2001) menemukan adanya korelasi signifikan antara arus kas dengan laba, tetapi tidak signifikan antara reaksi investor terhadap pengumuman laporan arus kas. Mulya (2009) menyimpulkan bahwa laba akuntansi memiliki pengaruh dan relevansi nilai yang positif terhadap harga saham; variabel arus kas operasi memiliki relevansi nilai yang positif tetapi tidak memiliki pengaruh signifikan terhadap harga saham. Yocelyn dan Christiawan (2012) menyatakan bahwa pengungkapan laba akuntansi berpengaruh signifikan terhadap return saham. Hal ini menandakan bahwa investor mempertimbangkan informasi laba akuntansi yang diungkapkan dalam laporan tahunannya untuk membuat keputusan. Sedangkan informasi perubahan arus kas di ketiga komponen terbukti tidak berpengaruh secara signifikan terhadap return saham. Yuliantari dan Sujana (2014) menyimpulkan bahwa arus kas operasi tidak berpengaruh secara signifikan terhadap return saham. Penelitian Putriani dan Sukartha (2014) menyimpulkan: arus kas bebas tidak berpengaruh secara signifikan pada return 
saham, sedangkan laba bersih memiliki pengaruh positif yang signifikan pada return saham. Motivasi penelitian ini, karena masih ditemukan hasil penelitian sebelumnya yang tidak konsisten. Tujuan penelitian ini untuk menguji dan mendapatkan bukti empiris tentang kandungan informasi arus kas dan laba akuntansi mempunyai pengaruh terhadap return saham pada perusahaan yang terdaftar dalam indeks LQ45 di sekitar tanggal pengumuman laporan keuangan.

\section{KAJIAN TEORI}

\section{Teori Pesinyalan (Signalling Theory)}

Teori Pesinyalan (Signalling Theory). Signalling theory menekankan kepada pentingnya informasi yang dikeluarkan oleh perusahaan terhadap keputusan investasi pihak di luar perusahaan. Informasi merupakan unsur penting bagi investor dan pelaku bisnis karena informasi pada hakekatnya menyajikan keterangan, catatan atau gambaran baik untuk keadaan masa lalu, saat ini maupun keadaan masa yang akan datang bagi kelangsungan hidup suatu perusahaan dan bagaimana penjualan efeknya. Menurut Jama'an (2008), Signaling Theory mengemukakan tentang bagaimana seharusnya sebuah perusahaan memberikan sinyal kepada pengguna laporan keuangan. Sinyal ini berupa informasi mengenai apa yang sudah dilakukan oleh manajemen untuk merealisasikan keinginan pemilik.

\section{Laba Akuntansi dan Return Saham.}

Menurut Horne dan Wachowicz (1997:24) earning adalah laba bersih yaitu laba bruto dikurangi biaya operasi yakni biaya sewa, pemasaran, pajak, gaji, upah, listrik dan penyusutan bunga. SFAC No. 1 menyatakan bahwa laba akuntansi adalah alat ukur yang baik untuk mengukur kinerja perusahaan dan bahwa laba akuntansi bisa digunakan untuk meramalkan aliran kas perusahaan (Hendriksen dan Van Breda, 2001: 311).

Menurut Tandelilin (2010:7) alasan utama orang berinvestasi adalah untuk memperoleh keuntungan. Tanpa adanya tingkat keuntungan yang dinikmati dari suatu investasi, tentunya investor tidak akan melakukan investasi. Jadi semua investasi mempunyai tujuan utama mendapatkan return (Ang, 1997: 202). Menurut Brigham dan Houston (2006: 215), return atau tingkat pengembalian adalah selisih antara jumlah yang diterima dan jumlah yang diinvestasikan, dibagi dengan jumlah yang diinvestasikan. Sedangkan menurut Samsul (2006: 291), return adalah pendapatan yang dinyatakan dalam persentase dari modal awal investasi.

Menurut Tandelilin (2010:48), return saham terdiri dari dua komponen, yaitu: (1) Capital gain (loss), yaitu kenaikan (penurunan) harga suatu saham yang bisa memberikan keuntungan (kerugian) bagi investor dan (2) Yield, yaitu komponen return yang mencerminkan aliran kas atau pendapatan yang diperoleh secara periodik dari suatu investasi saham.

Model Penelitian dan Pengembangan Hipotesis

Model Penelitian dalam penelitian ini dapat digambarkan sebagai berikut :

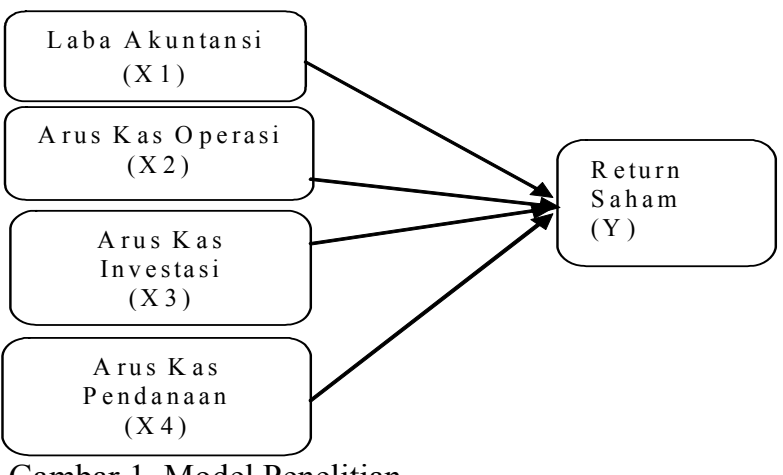

Gambar 1. Model Penelitian

\section{Pengembangan Hipotesis}

Pengaruh Laba Akuntansi terhadap Return Saham.

Dasar pengembangan penelitian yang berkaitan antara laba akuntansi dengan harga saham telah dilakukan oleh Ball dan Brown (1968). Hasil studi mereka menemukan bahwa perusahaan dengan laba meningkat atau menurun juga berhubungan dengan kenaikan atau penurunan harga saham selama periode pengamatan. Hasil studi Ball dan Brown (1968) kemudian menjadi dasar replikasi dan perluasan dalam berbagai studi yang berkaitan dengan laba. Beberapa hasil studi yang menunjukkan adanya hubungan pengumuman laba dengan harga saham telah banyak dilakukan, seperti Beaver et al. (1979, 1980), Foster et al. (1984), Bernard dan Thomas (1992), dan Kothari dan Sloan (1992) dalam kutipan Triyono dan Jogiyanto (2000). Hasil penelitian Yocelyn dan Christiawan (2012) terhadap 97 perusahaan yang memiliki kapitalisasi besar yang terdaftar di Bursa Efek Indonesia pada tahun 20092010 menyimpulkan bahwa laba akuntansi berpengaruh signifikan terhadap return saham. Berdasarkan pada uraian mengenai pengaruh laba akuntansi terhadap return saham di atas, maka hipotesis dalam penelitian ini adalah:

$\mathbf{H}_{\mathbf{1}}$ :Laba akuntansi berpengaruh signifikan terhadap 
return saham.

\section{Pengaruh Arus Kas Operasi terhadap Return Saham}

Triyono dan Jogiyanto (2000) menyimpulkan bahwa komponen arus kas dari kegiatan operasi mempunyai hubungan yang signifikan dengan harga saham. Penelitian Pradhono dan Christiawan (2004) menyimpulkan bahwa variabel arus kas operasi berpengaruh paling signifikan terhadap return yang diterima pemegang saham. Hasil penelitian Ginting (2012) menunjukkan bahwa arus kas operasi berpengaruh signifikan terhadap return saham. Menurut penulis, semakin tinggi arus kas operasional perusahaan maka semakin tinggi kepercayaan investor pada perusahaan tersebut, sehingga semakin besar pula nilai expected return saham. Dan sebaliknya, semakin rendah arus kas operasional perusahaan maka semakin kecil kepercayaan investor pada perusahaan tersebut, sehingga semakin kecil pula nilai expected return saham. Berdasarkan pada uraian mengenai pengaruh arus kas operasi terhadap return saham di atas, maka hipotesis dalam penelitian ini adalah:

$\mathbf{H}_{\mathbf{2}}$ :Arus kas operasi berpengaruh signifikan terhadap return saham

\section{Pengaruh Arus Kas Investasi terhadap Return Saham}

Aktivitas investasi mencerminkan pengeluaran kas sehubungan dengan sumber daya yang bertujuan untuk menghasilkan pendapatan dan arus kas masa depan. Hasil penelitian Arlina, Sinarwati dan Musmini (2014) menunjukkan terdapat pengaruh signifikan arus kas investasi terhadap return saham. Berdasarkan pada uraian mengenai pengaruh arus kas investasi terhadap return saham di atas, maka hipotesis dalam penelitian ini adalah:

$\mathbf{H}_{3}$ : Arus kas investasi berpengaruh signifikan terhadap return saham.

\section{Pengaruh Arus Kas Pendanaan terhadap Return Saham.}

Dalam kutipan Triyono dan Jogiyanto (2000), Smith (1986) mengemukakan berdasarkan teori keuangan bahwa penerbitan atau penarikan saham biasa akan berpengaruh terhadap return saham. Investor yang diasumsikan mempunyai informasi khusus mengenai perusahaan akan bereaksi negatif terhadap pengumuman pengeluaran saham baru dan akan bereaksi positif terhadap pengumuman penarikan saham. Mikellson dan Partch (1986), Asquith dan Mullins (1986) memberikan bukti empiris bahwa pasar bereaksi negatif terhadap pengumuman penerbitan saham baru. Sinyal lain yang berpengaruh terhadap arus kas dari pendanaan adalah model dari Miller dan Rock (1985) yang memprediksikan bahwa perubahan deviden berhubungan dengan return saham. Deviden yang meningkat memberi sinyal terhadap arus kas masa yang akan datang yang diharapkan berhubungan positif dengan return saham. Bukti empiris Asquith dan Mullins (1983), Brickley (1983) juga menemukan bahwa perubahan deviden mempunyai pengaruh yang signifikan dengan return saham. Berdasarkan pada uraian mengenai pengaruh arus kas investasi terhadap return saham di atas, maka hipotesis dalam penelitian ini adalah:

$\mathbf{H}_{\mathbf{4}}$ :Arus kas pendanaan berpengaruh signifikan terhadap return saham.

\section{METODE}

Data yang dipergunakan adalah data sekunder berupa laporan keuangan tahunan dan harga saham yang dipublikasikan tahun 2011 sampai 2014. Populasi dalam penelitian ini adalah seluruh perusahaan yang terdaftar dalam indeks LQ 45 selama tahun 2011 sampai 2014. Metode pemilihan sampel yang digunakan adalah metode purposive sampling yang didasarkan kriteria sebagai berikut: (1) Perusahaan terdaftar dalam indeks LQ 45 selama empat tahun berturut-turut yaitu tahun 2011 sampai 2014 dengan minimal terdaftar satu semester setiap tahun periode tersebut; (2) Memiliki laporan keuangan secara lengkap selama empat tahun berturut-turut dengan periode tahunan dan telah diaudit oleh Kantor Akuntan Publik; (3) Menggunakan Rupiah sebagai mata uang pelaporan keuangan; (4) Tanggal pelaporan dan pengumuman laporan keuangan tersedia sebagai data yang menentukan periode pengamatan harga saham.

Dari 45 perusahaan yang terdaftar dalam Indeks LQ 45, hanya 20 perusahaan yang memenuhi keempat syarat di atas. Namun dalam proses pengolahan data terdapat 5 perusahaan yang memiliki data outlier yang harus dikeluarkan dari penelitian ini. Dengan demikian data yang dapat digunakan dalam penelitian ini adalah 15 perusahaan sampel dengan periode penelitian selama 4 tahun sehingga terkumpul jumlah sampel sebanyak 60 sampel (15 perusahaan $\mathrm{x} 4$ periode).

Teknik analisis data yang digunakan dalam penelitian ini adalah teknik analisis data panel yang diolah dengan menggunakan program Eviews 8.0. Untuk mengetahui seberapa besar independent 
variable mempengaruhi dependent variable dihitung dengan menggunakan persamaan garis regresi sebagai berikut:

$$
y_{i t}=\alpha+\boldsymbol{\beta}^{\prime} \boldsymbol{X}_{i t}+u_{i}+\varepsilon_{i t}
$$

Dalam hal ini:

Untuk $\mathrm{i}=1,2, \ldots, \mathrm{N}$ dan $\mathrm{t}=1,2, \ldots, \mathrm{T}$.

Dimana

$\mathrm{N}=$ jumlah individu atau cross section

$\mathrm{T}=$ jumlah periode waktunya.

$\alpha=$ Konstanta

$\beta^{*}=$ Vektor berukuran Px1 merupakan parameter hasil estimasi

$X_{i t}=$ Observasi ke-it dari $\mathrm{P}$ variabel bebas

$\varepsilon_{i t}=$ residual secara menyeluruh dimana

residual tersebut merupakan kombinasi dari cross section dan time series.

$u_{\mathrm{i}}=$ residual secara individual yang merupakan karakteristik random dari observasi unit ke-i dan tetap sepanjang waktu.

Untuk menguji signifikansi model digunakan alat uji ANOVA (F-test) dan untuk menguji signifikansi koefisien regresi digunakan alat uji-t (t-test). Uji-F dilakukan untuk mengetahui pengaruh independent variable mempunyai kelayakan model atau penelitian ini mempunyai model yang baik. Dengan cara menentukan tingkat signifikansi sebesar 5\% $(\alpha=0,05)$, kemudian membandingkan F-hitung dengan F-tabel, apabila F-hitung $<$ F-tabel berarti independent variable secara simultan tidak berpengaruh terhadap dependent variable, sedangkan apabila F-hitung $>$ F-tabel berarti independent variable secara simultan berpengaruh terhadap dependent variable (Gujarati, 2010). Sedangkan uji-t dilakukan untuk mengetahui signifikansi pengaruh dari seluruh independent variable secara parsial terhadap dependent variable. Pada uji-t, nilai t-hitung akan dibandingkan dengan nilai t-tabel.
Jika nilai t-hitung $>$ dari nilai t-tabel, maka $\mathrm{H}_{0}$ ditolak dan $\mathrm{H}_{\mathrm{a}}$ diterima yang berarti independent variable berpengaruh terhadap dependent variable.

\section{HASIL DAN PEMBAHASAN}

Tabel 2 menggambarkan perkembangan variabel penelitian selama tahun 2011-2014. Dengan jumlah data sampel sebanyak 60, maka pada variabel laba akuntansi diperoleh nilai minimum sebesar -0,39525 dimiliki oleh emiten JSMR pada tahun 2014, sedangkan nilai laba akuntansi tertinggi adalah sebesar 0,96875 dimiliki oleh emiten KLBF terjadi pada tahun 2014. Nilai mean laba akuntansi sebesar 0,1341118 dengan standar deviasi sebesar 0,24981336 . Variabel arus kas operasi dari 60 data yang ada, diperoleh nilai minimum sebesar $-2,61300$ dimiliki oleh emiten LPKR terjadi pada tahun 2013, sedangkan nilai maksimum adalah sebesar 2,44376 dimiliki oleh emiten ASII terjadi pada tahun 2011. Sedangkan nilai mean adalah sebesar-0,0168590 dan standar deviasi sebesar 0,82519799. Variabel arus kas investasi dari 60 data yang ada, diperoleh nilai minimum sebesar -16,68465 dimiliki oleh emiten BMRI terjadi pada tahun 2013, sedangkan nilai maksimum adalah sebesar 29,99573 dimiliki oleh emiten LPKR terjadi pada tahun 2011. Sedangkan nilai mean adalah sebesar 0,4217257 dan standar deviasi sebesar 4,83816392. Variabel arus kas pendanaan dari 60 data yang ada, diperoleh nilai minimum sebesar $-10,53732$ dimiliki oleh emiten BMRI terjadi pada tahun 2011, sedangkan nilai maksimum adalah sebesar 12,14463 dimiliki oleh emiten CPIN terjadi pada tahun 2014. Sedangkan nilai mean adalah sebesar 0,0019097 dan standar deviasi sebesar 2,76186795. Variabel return saham dari 60 data yang ada, diperoleh nilai minimum sebesar -0,00635 dimiliki oleh emiten CPIN terjadi pada tahun 2014, sedangkan nilai maksimum adalah sebesar 0,1354 dimiliki oleh emiten LPKR terjadi pada

Tabel 2. Statistik Deskriptif

\begin{tabular}{lccccc}
\hline & $\begin{array}{c}\text { X1 (Laba } \\
\text { Akuntansi) }\end{array}$ & $\begin{array}{c}\text { X2 (Arus Kas } \\
\text { Operasi) }\end{array}$ & $\begin{array}{c}\text { X3 (Arus Kas } \\
\text { Investasi) }\end{array}$ & $\begin{array}{c}\text { X4 (Arus Kas } \\
\text { Pendanaan) }\end{array}$ & $\begin{array}{c}\text { Y (Return } \\
\text { Saham) }\end{array}$ \\
\hline Mean & 0.134112 & -0.016859 & 0.421726 & 0.040913 & 0.001909 \\
Median & 0.113455 & 0.034040 & 0.135680 & -0.052925 & 0.001020 \\
Maximum & 0.968750 & 2.443760 & 29.99573 & 12.14463 & 0.013540 \\
Minimum & -0.395250 & -2.613000 & -16.68465 & -10.53732 & -0.006350 \\
Std. Dev. & 0.249813 & 0.825198 & 4.838164 & 2.761868 & 0.004639 \\
Skewness & 0.354822 & -0.060304 & 2.949380 & 0.936115 & 0.387943 \\
Kurtosis & 4.455132 & 6.136001 & 27.42549 & 11.91494 & 2.568368 \\
Jarque-Bera & 6.552509 & 24.62262 & 1578.500 & 207.4534 & 1.970765 \\
Probability & 0.037769 & 0.000005 & 0.000000 & 0.000000 & 0.373296 \\
Sum & 8.046710 & -1.011540 & 25.30354 & 2.454760 & 0.114550 \\
Sum Sq. Dev. & 3.681996 & 40.17615 & 1381.062 & 450.0470 & 0.001270 \\
\hline Observations & 60 & 60 & 60 & 60 & 60 \\
\hline
\end{tabular}


tahun 2012. Sedangkan nilai mean adalah sebesar 0,0019097 dan standar deviasi sebesar 0,00463843.

Pengujian asumsi klasik yang akan dilakukan adalah uji normalitas, uji autokorelasi, uji multikolinieritas dan uji heterokedastisitas. Uji normalitas bertujuan untuk menguji apakah variabel residual berdistribusi normal. Uji statistik yang digunakan dalam penelitian ini adalah uji statistik nonparametrik Kolmogorov-Smirnov.

Tabel 3. Hasil Uji Normalitas

Hypothesis Test Summary

\begin{tabular}{|cccc|}
\hline Null Hypothesis & Test & Sig. & Decision \\
\hline $\begin{array}{l}\text { The distribution of Unstandardized One-Sample } \\
\text { Residual is normal with mean } 0,000 \text { Kolmogorov. } \\
\text { and standard deviation } 0,00 .\end{array}$ & Smirnov Test & ,703 $\begin{array}{l}\text { Retain the } \\
\text { null } \\
\text { hypothesis. }\end{array}$ \\
\hline
\end{tabular}

Asymptotic signific ances are displayed. The significance level is, 05 .

Hasil analisis metode One-Sample KolmogorovSmirnov, menunjukkan bahwa Nilai signifikansi sebesar 0,703 (Asyimpthoted Sig. (2-tailed)). Persyaratan data disebut normal jika probabilitas atau p $>0,05$ pada uji normalitas dengan Kolmogorov Smirnov. Oleh karena nilai signifikannya $>0,05$ maka data berdistribusi normal. Model yang baik adalah jika tidak terjadi korelasi antar independent variable. Mendeteksi multikolinearitas antar independent variable dilakukan dengan nilai VIF (variance inflation factors). Jika VIF $<10$ maka dikatakan tidak terjadi multikolinearitas.

Tabel 4. Hasil Uji Multikolinearitas Coefficients $^{a}$

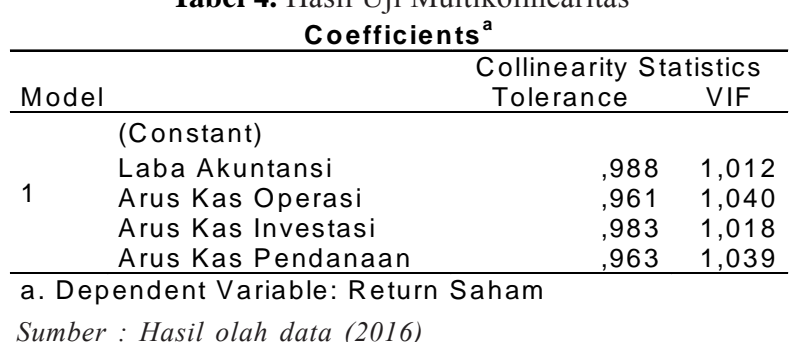

Berdasarkan tabel 4 terlihat bahwa nilai toleransi laba akuntansi sebesar 0,988 , arus kas operasi sebesar 0,961, arus kas investasi sebesar 0,983 dan arus kas pendanaan sebesar 0,963. Hal ini menunjukkan bahwa tidak ada variabel yang memiliki nilai tolerance kurang dari 0,1 , ini berarti dalam model regresi yang dihasilkan tidak terjadi multikolinieritas. Sedangkan besarnya nilai VIF untuk semua independent variable memperlihatkan nilai $\mathrm{VIF}<10$. Dengan demikian berdasarkan hasil uji tersebut disimpulkan tidak terjadi korelasi antar independent variabel dalam penelitian ini.

Untuk melihat ada atau tidaknya korelasi yang terjadi antara residual pada satu pengamatan dengan pengamatan lain digunakan Uji Durbin Watson (uji DW). Setelah dilakukan pengujian, maka diperoleh hasil seperti yang tertera pada Tabel 5 berikut ini:

Tabel 5. Hasil Uji Autokorelasi

\begin{tabular}{c}
\hline Durbin-Watson \\
\hline 2,012626 \\
\hline
\end{tabular}

Pada jumlah $\mathrm{k}=\mathrm{jumlah}$ independent variable $=4$, jumlah sampel $=60$, Tabel Durbin Watson menunjukkan nilai $\mathrm{dL}=1,444$ dan $\mathrm{du}=1,727$ serta 4 $d u=2,273$. Nilai $D W$ hasil pengujian $=2,013$. Dengan demikian $\mathrm{du}<\mathrm{d}<4$-du $(1,727<2,013<2,273)$ sehingga dapat disimpulkan tidak terjadi autokorelasi.

Pengujian heteroskedastisitas dilakukan dengan Uji Glejser. Uji Glejser dilakukan dengan menguji pengaruh independent variable terhadap nilai absolute residual model. Jika hasil uji pengaruh masing-masing independent variable terhadap nilai absolute residual tersebut tidak signifikan maka tidak terjadi heteroskedastisitas.

Hasil uji t independent variable (laba akuntansi, arus kas operasi, arus kas investasi dan arus kas pendanaan) terhadap Absolut nilai residual menunjukkan nilai diatas 0,05 yang berarti tidak signifikan. Hal ini menunjukkan bahwa tidak terjadi heteroskedastisitas.

Uji F merupakan pengujian keseluruhan independent variable terhadap dependent variable secara bersama-sama (simultan). Pengujian ini dilakukan untuk tujuan menguji baik ( $f i t)$ tidaknya model penelitian yang diuji. Model dikatakan baik (fit) jika hasil uji probabilitas Uji $\mathrm{F}<0,05$ (5\%).

Tabel 6. Hasil Uji Heteroskedastisitas

\begin{tabular}{|c|c|c|c|c|c|c|}
\hline \multicolumn{7}{|c|}{ Coefficients ${ }^{a}$} \\
\hline & & \multicolumn{2}{|c|}{$\begin{array}{c}\text { Unstandardized } \\
\text { Coefficients }\end{array}$} & $\begin{array}{l}\text { Standardized } \\
\text { Coefficients }\end{array}$ & & \\
\hline \multicolumn{2}{|c|}{ Model } & $\mathrm{B}$ & Std. Error & Beta & $\mathrm{t}$ & Sig. \\
\hline \multirow{5}{*}{1} & (Constant) &, 003 &, 000 & & 8,917 &, 000 \\
\hline & Laba Akuntansi &,- 001 & 001 &,- 125 &,- 939 &, 352 \\
\hline & Arus Kas Operasi &, 000 & 000 &, 114 & 848 & 400 \\
\hline & Arus Kas Investasi & $2,660 \mathrm{E}-005$ &, 000 &, 049 &, 369 &, 713 \\
\hline & Arus Kas Pendanaan & 000 &, 000 &,- 151 & $-1,124$ & 266 \\
\hline
\end{tabular}

a. Dependent Variable: ABSUT 
Jika hasil Uji $\mathrm{F}<0,05$ maka paling tidak satu diantara independent variable yang diuji dapat dipastikan berpengaruh terhadap dependent variable nya.

Tabel 7. Hasil Uji F

\begin{tabular}{cc}
\hline F-statistic & Prob(F-statistic) \\
2.996396 & 0.026173 \\
\hline
\end{tabular}

Dari uji ANOVA atau F test, diperoleh F hitung sebesar 2,996 dengan tingkat signifikansi 0,026 lebih kecil dari 0,05. Berdasarkan hasil tersebut dapat disimpulkan bahwa laba akuntansi, arus kas operasi, arus kas investasi dan arus kas pendanaan mempunyai kelayakan model (Goodness of Fit) independent variabel terhadap return saham pada perusahaan LQ45. Penelitian ini memberikan informasi bahwa return saham dapat diprediksi berdasarkan informasi dari laba akuntansi, arus kas operasi, arus kas investasi dan arus kas pendanaan. Dengan demikian investor dalam melakukan kegiatan di pasar modal dapat menggunakan keempat informasi tersebut dalam menentukan investasinya.

Hasil Uji koefisien determinasi menunjukkan kemampuan independent variable menjelaskan dependent variable, berikut ini.

Tabel 8. Hasil Uji Koefisien Determinasi

\begin{tabular}{ccc} 
R-squared & Adjusted R-squared & $\%$ \\
0.178928 & 0.119213 & $11.9 \%$ \\
\hline
\end{tabular}

Tabel 8 ini menerangkan nilai koefisien determinasi dari pengaruh laba akuntansi, arus kas operasi, arus kas investasi dan arus kas pendanaan terhadap return saham. Angka Adjusted R-squared adalah 0,119 . Hal ini berarti $11,9 \%$ return saham dipengaruhi oleh laba akuntansi, arus kas operasi, arus kas investasi dan arus kas pendanaan. Sedangkan selebihnya $88,1 \%$ karena faktor lain yang tidak diobservasi dalam penelitian ini.

Uji t digunakan untuk mengetahui pengaruh masing-masing variabel bebas terhadap variabel terikat. Hasil pengujian hipotesis dengan menggunakan uji t dapat dilihat pada tabel berikut ini

Hasil penelitian ini membuktikan bahwa laba akuntansi tidak berpengaruh secara signifikan terhadap return saham perusahaan LQ45. Dengan demikian hasil penelitian ini mendukung penelitian Irianti (2008) dan Adiwiratama (2012) yang menyatakan bahwa laba akuntansi tidak berpengaruh signifikan terhadap return saham. Berbeda dengan penelitian penelitian Ferry dan Erni (2004) dan Yocelyn dan Christiawan (2012) yang membuktikan bahwa laba akuntansi berpengaruh terhadap return saham. Hal ini mungkin disebabkan karena informasi akuntansi perusahaan sampel tidak mengandung informasi yang relevan dan masih terjadi anomali pasar diakibatkan kegagalan investor memahami informasi akrual, arus kas, risiko pasar dan konservatisma.

Arus kas dari kegiatan operasi dapat menjadi perhatian penting karena dalam jangka panjang untuk kelangsungan hidup perusahaan, suatu bisnis harus menghasilkan arus kas bersih yang positif dari kegiatan operasi. Hasil penelitian ini membuktikan bahwa arus kas operasi berpengaruh positif dan signifikan terhadap return saham perusahaan LQ45. Temuan ini konsisten dengan penelitian sebelumnya oleh Irianti (2008), Ardiansyah (2012) dan Arlina (2014) yang menyatakan komponen arus kas operasi mempunyai pengaruh yang positif dengan return saham.

Hasil penelitian ini membuktikan bahwa arus kas investasi tidak berpengaruh signifikan terhadap return saham. Investor tidak melihat pelaporan perubahan arus kas dari aktivitas investasi tersebut sebagai informasi yang dapat digunakan untuk pengambilan keputusan investasinya. Hal ini mengindikasikan bahwa arus kas dari aktivitas investasi bukan merupakan informasi yang relevan bagi investor sebagai dasar pengambilan keputusan investasi. Arus kas investasi tidak berpengaruh secara signifikan terhadap return saham, karena kandungan informasi akuntansi pada perusahaan sampel tidak mengandung informasi yang relevan dan masih terjadi anomali pasar diakibatkan kegagalan investor memahami informasi akrual, arus kas, risiko pasar dan konservatisma. Temuan ini sesuai dengan hasil penelitian Ferry dan Erni (2004), Irianti (2008), Yocelyn dan Chritiawan (2012), Meithy (2012) dan

Tabel 9. Hasil Uji t

\begin{tabular}{ccccc}
\hline Variable & Coefficient & Std. Error & t- Statistic & Prob. \\
\hline X1 (Laba Akuntansi) & 0.000392 & 0.002204 & 0.177888 & 0.8595 \\
X2 (Arus Kas Operasi) & 0.001501 & 0.000682 & 2.201077 & 0.0319 \\
X3 (Arus kas Investasi) & -0.000171 & 0.000113 & -1.522184 & 0.1337 \\
X4 (Arus Kas Pendanaan) & -0.000474 & 0.000201 & -2.354468 & 0.0221 \\
C (Koefisien) & 0.001974 & 0.000700 & 2.819089 & 0.0067 \\
\hline
\end{tabular}


Purwanti (2015). Namun bertolak belakang dengan hasil penelitian Triyono dan Jogyanto (2000) dan Daniati (2006) yang menyimpulkan bahwa arus kas dari aktifitas investasi berpengaruh terhadap harga dan return saham.

Hasil penelitian ini membuktikan bahwa arus kas pendanaan berpengaruh signifikan terhadap return saham perusahaan LQ45. Hal ini berarti setiap peningkatan pengeluaran untuk aktivitas pendanaan diikuti dengan peningkatan return saham. Temuan ini konsisten dengan penelitian Triyono dan Jogyanto (2000), Purwanti (2015), Arlina (2014), Trisnawati (2013) dan Adiwiratama (2012) yang menyatakan bahwa arus kas pendanaan berpengaruh positif terhadap return saham. Namun hasil penelitian ini bertolak belakang dengan penelitian Ferry dan Erni (2004) serta Irianti (2008) yang membuktikan arus kas pendanaan tidak berpengaruh signifikan terhadap return saham.

\section{SIMPULAN DAN SARAN}

\section{Simpulan}

Hasil pengujian hipotesis menunjukkan bahwa:

1. Laba akuntansi tidak berpengaruh terhadap return saham, karena informasi akuntansi perusahaan sampel tidak mengandung informasi yang relevan dan masih terjadi anomali pasar diakibatkan kegagalan investor memahami informasi akrual, arus kas, risiko pasar dan konservatisma.

2. Arus kas dari kegiatan operasi dapat menjadi perhatian penting karena dalam jangka panjang untuk kelangsungan hidup perusahaan, suatu bisnis harus menghasilkan arus kas bersih yang positif dari kegiatan operasi. Hasil penelitian ini membuktikan bahwa arus kas operasi berpengaruh positif dan signifikan terhadap return saham perusahaan LQ45.

3. Arus kas investasi tidak berpengaruh signifikan terhadap return saham, karena Investor tidak melihat pelaporan perubahan arus kas dari aktivitas investasi tersebut sebagai informasi yang dapat digunakan untuk pengambilan keputusan investasinya.

4. Arus kas pendanaan berpengaruh signifikan terhadap return saham perusahaan LQ45. Hal ini berarti setiap peningkatan pengeluaran untuk aktivitas pendanaan diikuti dengan peningkatan return saham.

\section{Keterbatasan Penelitian}

1. Penelitian ini tidak random sehingga tidak dapat digunakan sebagai dasar generalisasi.

2. Jumlah sampel yang relatif sedikit, hanya 60 data yang diobservasi.

\section{Saran}

1. Para investor maupun calon investor serta praktisi pasar modal yang akan menggunakan informasi dari penelitian ini perlu mempertimbangkan faktor fundamental dan faktor teknikal lainnya, agar tidak terjadi kesalahan dalam mengambil keputusan investasi serta analisis dan peramalan terhadap harga saham perusahaan.

2. Penelitian selanjutnya dapat menambahkan variabel penelitian yang lain seperti: kualitas laba, volatilitas harga saham, volume perdagangan saham, inflasi, tingkat suku bunga, nilai tukar dan lain-lain.

3. Peneliti selanjutnya diharapkan dapat menambah jumlah sampel yang lebih besar dengan memperpanjang periode pengamatan dan obyek penelitian tidak hanya berfokus pada perusahaan yang terdaftar dalam indeks LQ45, tetapi juga perusahaan go public lainnya, sehingga diharapkan dapat memberikan hasil yang lebih baik dan akurat yang dapat digeneralisasi untuk keseluruhan perusahaan di Indonesia.

\section{DAFTAR PUSTAKA}

Ang, Robbert, (1997). Buku Pintar Pasar Modal Indonesia. Edisi Pertama. MediaSoft Indonesia.

Ardiansyah, Ali dan Djaya, (2012). Hubungan Informasi Komponen Arus Kas dan Return on Investment Terhadap Return Saham. Jurnal Manjemen dan Keuangan, Fakultas Ekonomi dan Bisnis, Universitas Hasanuddin, Makassar.

Arlina, Sinarwati dan Musmini, (2014). Pengaruh Informasi Arus Kas, Laba Kotor, Ukuran Perusahaan, dan Return on Asset (ROA) Terhadap Return Saham. E-journal Akuntansi Universitas Pendidikan Ganesha, Volume 2, No.1 Tahun 2014.

Ball, R dan P. Brown (1968). An Empirical Evalution of Accounting Income Numbers, Journal of Accounting Research Vol.6, Hal. 159-178.

Brigham, Eugene, F and Joel F. Houston, (2001). Financial Management (Manajemen Keuangan). Terjemahan Dodo Suharto dan Herman Wibowo. Buku I. Gelora Akasara, Jakarta

Daniati, N. dan Suhairi (2006). Pengaruh Kandungan Informasi Komponen Laporan Arus Kas, Laba Kotor, dan Size Perusahaan terhadap Expected Return Saham pada Perusahaan Textile dan Automotive di Bursa Efek Jakarta. Simposium Nasional Akuntansi IX, 
Padang. Vol. 3, No. 1.

Ferry dan Erni Eka Wati, (2004). Pengaruh Informasi Laba Aliran Kas dan Komponen Aliran Kas Terhadap Harga Saham Pada Perusahaan Manufaktur Di Indonesia. Simposium Nasional Akuntansi VII, Hal. 1122-1133.

Ginting, Suriani (2012). Analisis Pertumbuhan Arus Kas dan Profitabilitas Terhadap Return Saham Pada Perusahaan LQ45 di Bursa Efek Indonesia. Jurnal Wira Ekonomi Mikroskil, Volume 2, Nomor 01, April 2012.

Hastuti, AW, (1997). Pengaruh Publikasi Laporan Arus Kas Terhadap Volume Perdagangan Saham di Bursa Efek Jakarta. Simposium Nasional Akuntansi I.

Hendriksen, E.S. dan M.F. Van Breda (2001). Accounting Theory, Edisi 5, Mc. Graw-Hill, New York.

Horne, Van dan Wachowicz Jr, (1997), Financial Management. Edisi 12, Salemba Empat, Jakarta.

Irianti, T.E., (2008). Pengaruh Kandungan Informasi, arus Kas dan Laba Akuntansi dengan Harga dan Return Saham. Ringkasan Tesis. Universitas Diponegoro, Semarang.

Ikatan Akuntan Indonesia, (2009). Standar Akuntansi Keuangan-Per 1Juli 2009. Salemba Empat, Jakarta.

Jama'an, (2008). Pengaruh Mekanisme Corporate Governance dan Kualitas Kantor Akuntan Publik Terhadap Integritas Informasi laporan Keuangan. Jurnal Akuntansi dan Keuangan, hal: 43-52

Jogiyanto, (2008). Teori Portofolio dan Analisis Investasi. Edisi Kelima. Yogyakarta: BPFE UGM.

Jundan Adiwiratama, (2012). Pengaruh Informasi Laba, Arus Kas Dan Size Perusahaan Terhadap Return Saham (Studi Empiris Pada Perusahaan Manufaktur Yang Terdaftar Di BEI). Jurnal Ilmiah Akuntansi Dan Humanika JINAH, Vol. 2, No. 1, Desember 2012.

Livnat, J. dan Paul Zarowin, (1990). The Incremental Information Content of Cash Flow Components. Journal of Accounting and Economics, 13.

Meythi dan Selvy Hartono, (2012). Pengaruh Informasi Laba dan Arus Kas Terhadap Harga Saham. Akurat Jurnal Ilmiah Akuntansi, No. 07, Tahun Ke-3, Januari-April 2012.

Mulya, Anissa Amalia, (2009). Analisis Relevansi Informasi Laba Akuntansi, Nilai Buku Ekuitas dan Arus Kas Operasi dengan Harga Saham (Studi Empirik Pada Perusahaan Manufaktur Yang Terdaftar di Bursa Efek Indonesia Periode 2004-2008). Fakultas Ekonomi Universitas Budi Luhur, Jakarta.

Pratama, S. dan Akbar, DA., (2014). Pengaruh Laba Akuntansi dan Komponen Arus Kas Terhadap Return Saham Perusahaan Manufaktur yang Terdaftar di Bursa Efek Indonesia. Jurnal STIE MDP.

Pradhono dan Y.J. Christiawan, (2004). Pengaruh Economic Value Added, Residual Income, Earnings Dan Arus Kas Operasi Terhadap Return Yang Diterima Oleh Pemegang Saham. Jurnal Akuntansi \& Keuangan, Vol. 6, No. 2, Nopember 2004, Hal. 140-166

Purwanti, Masitoh, dan Chomsatu, (2015).Pengaruh Laba Akuntansi dan Arus Kas Terhadap Return Saham yang Listing di BEI. Jurnal. Universitas Islam Batik Surakarta.

Putriani, Ni Putu dan I Made Sukartha, (2014). Pengaruh Arus Kas Bebas dan Laba Bersih pada Return Saham Perusahaan LQ-45. E-Jurnal Akuntansi Universitas Udayana 6.3 (2014), Hal. 390-401.

Rohman, A, (2001). Pengaruh Arus Kas Operasi Dan Laba Akuntansi Terhadap Tingkat Keuntungan Dan Likuiditas Saham Emiten di Bursa Efek Jakarta. Simposium Nasional Akuntansi IV.

Samsul, Mohammad. (2006). Pasar Modal dan Manajemen Portofolio. Surabaya: Erlangga.

Tandelilin, E, (2010). Analisis Investasi dan Manajemen Portofolio. Edisi Revisi. BPFE UGM, Yogyakarta.

Trisnawati, W. dan Wahidahwati, (2013). Pengaruh Arus Kas Operasi, Investasi Dan Pendanaan Serta Laba Bersih Terhadap Return Saham. Jurnal Ilmu dan Riset Akuntansi, Vol. 1, No. 1, Januari 2013

Triyono dan Jogiyanto Hartono, (2000). Hubungan Kandungan Informasi arus Kas, Komponen Arus Kas, dan Laba Akuntansi dengan Harga atau Return Saham. Jurnal Riset Akuntansi Indonesia, Vol. 3, No. 1, Hal. 54-68.

Yocelyn, A dan Y.J. Christiawan, (2012). Analisis Pengaruh Perubahan Arus Kas dan Laba Akuntansi Terhadap Return Saham pada Perusahaan Berkapitalisasi Besar. Jurnal Akuntansi Dan Keuangan, Vol. 14, No. 2, Hal. $81-90$

Yuliantari, Ni Ny.A dan I K. Sujana, (2014). Pengaruh Financial Ratio, Firm Size, dan Cash Flow Operating Terhadap Return Share Perusahaan F\&B. E-Jurnal Akuntansi Universitas Udayana 7.3 (2014), Hal. 547558. 